Discussion Paper No. 08-091

\title{
Clean and Productive?
} Evidence from the German Manufacturing Industry

Christoph Böhringer, Ulf Moslener, Ulrich Oberndorfer, and Andreas Ziegler

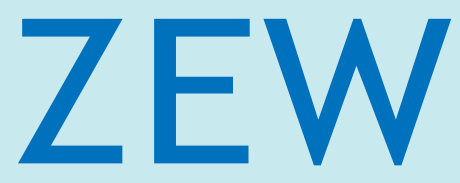

Zentrum für Europäische Wirtschaftsforschung $\mathrm{GmbH}$

Centre for European Economic Research 
Discussion Paper No. 08-091

\title{
Clean and Productive? Evidence from the German Manufacturing Industry
}

\author{
Christoph Böhringer, Ulf Moslener, \\ Ulrich Oberndorfer, and Andreas Ziegler
}

Download this ZEW Discussion Paper from our ftp server:

ftp://ftp.zew.de/pub/zew-docs/dp/dp08091.pdf

Die Discussion Papers dienen einer möglichst schnellen Verbreitung von neueren Forschungsarbeiten des ZEW. Die Beiträge liegen in alleiniger Verantwortung der Autoren und stellen nicht notwendigerweise die Meinung des ZEW dar.

Discussion Papers are intended to make results of ZEW research promptly available to other economists in order to encourage discussion and suggestions for revisions. The authors are solely responsible for the contents which do not necessarily represent the opinion of the ZEW. 


\section{Non-Technical Summary}

With the public opinion getting more aware of adverse environmental consequences of economic activities, many firms have improved environmental performance not only due to more stringent environmental regulation but also on a voluntary basis. However, empirical evidence on the economic effects of such improved environmental performance is rather scant to date. Against this background, this paper addresses economic impacts of firms' efforts towards cleaner production A production function approach where environmental investment as well as environmental and energy expenditures are explicitly considered as inputs provides the conceptual framework for our investigation.

In our empirical analysis for the German manufacturing industry, we employ both static and dynamic panel techniques taking into account possible complex causal relations of variables related to environmental performance and economic performance. Our results do not provide evidence for positive impacts of both environmental and energy expenditures on production growth. In contrast, environmental investment positively impinges upon productivity, indicating that environmental performance, as measured by environmental investment, may be a productivity driver. From a policy perspective, this finding suggests that, in order to be compatible with economic goals such as productivity, environmental regulation should stimulate investment.

\section{Das Wichtigste in Kürze}

Dieser Aufsatz untersucht die ökonomischen Effekte von Umweltaktivitäten in den Sektoren der deutschen verarbeitenden Industrie. Hierfür wird im Rahmen eines ProduktionsfunktionsAnsatzes die Rolle von Umwelt- und Energieausgaben sowie von Investitionen in umweltfreundliche Verfahren und Produkte untersucht. Nach unseren Ergebnissen sind sowohl Umwelt- als auch Energieausgaben „unproduktiv“, d.h. sie tragen nicht zur Steigerung der Produktion der untersuchten Sektoren bei. Im Gegensatz dazu befördern Investitionen in umweltfreundliche Verfahren und Produkte das Produktionswachstum der von uns untersuchten Industrien. Bei der Instrumentenwahl zur Umweltregulierung sollten demnach vor allem Maßnahmen in Betracht gezogen werden, die Investitionen stimulieren. 


\title{
Clean and Productive?
}

\section{Evidence from the German Manufacturing Industry}

\author{
Christoph Böhringer*, Ulf Moslener ^, Ulrich Oberndorfer*, Andreas Ziegler ${ }^{\#}$
}

November 2008

\begin{abstract}
We analyze the productivity effects of environmental (green) investment as well as of environmental expenditures and energy expenditures. For this purpose, we follow a production function approach where we account for these investment and expenditure categories as inputs. Based on a panel dataset for the German manufacturing industry between 1996 and 2002 we find that both environmental and energy expenditures do not contribute to production growth. In contrast, environmental investment positively impinges upon production growth as a productivity driver. We thus conclude that environmental regulation should stimulate investment in order to be compatible with economic goals such as productivity.
\end{abstract}

Keywords: environmental performance, environmental regulation, productivity

JEL classification: Q28, Q58, D24

Acknowledgement: The authors would like to thank Niels Anger, Ralf Martin, Elisabeth Müller, and seminar participants in Berlin, Mannheim and Oldenburg for helpful comments and suggestions. Christian Almer and Jörg Auth have provided valuable data support. Ulrich Oberndorfer gratefully acknowledges funding by the Anglo-German Foundation (AGF).

\footnotetext{
* Carl von Ossietzky University Oldenburg, and Centre for European Economic Research (ZEW), Germany, christoph.boehringer@uni-oldenburg.de

- Centre for European Economic Research (ZEW), Germany, moslener@zew.de

* Corresponding author. Centre for European Economic Research (ZEW), P.O. Box 103443, 68034 Mannheim, Germany, oberndorfer@zew.de

\# University of Zurich and ETH Zurich, Switzerland, andreas.ziegler@ccrs.uzh.ch
} 


\section{Introduction}

Will industries that are "greening" gain or loose in productivity? This question is crucial not only for managerial, but also for political decision-making if the policy agenda includes both economic as well as environmental goals. From a theoretical point of view, the question is controversially disputed within two complementary strands of scientific research. First, there is the debate on the economic impacts of environmental regulation, i.e. of policy measures aiming at a greener production: Traditional economic theory predicts negative economic effects of such regulation (Palmer et al., 1995), while the so-called Porter Hypothesis suggests economic gains from regulation due to innovation offsets in the regulated country (Porter and van der Linde, 1995). Second, there is the debate on the economic effects of voluntary measures of businesses that lead to a greener production ("environmental performance"). Similar to the case of environmental regulation the findings here are ambiguous (Telle, 2006). This paper picks up both strands of literature: Based on the theoretical framework of a production function approach that particularly accounts for capital inputs serving to environmental goals, we empirically analyze the economic effects of environmental investment and expenditures. Our econometric analysis refers to the German manufacturing industry and is based on the application of panel techniques that capture both unobserved heterogeneity over industries and time as well as dynamic adjustment processes.

There is a substantial literature on possible "innovation offsets" of environmental expenditures and regulation. Brunnermeier and Cohen (2003) find that pollution abatement and control expenditures (PACE) have a positive impact on environmental innovation at the U.S. industry level. Other studies such as Lanjouw and Mody (1996) and Pickman (1998) corroborate this result. In contrast, Jaffe and Palmer (1997) do not find empirical evidence for a positive effect of pollution abatement and control expenditures on - overall - innovation activity at the U.S. industry level. There are fewer empirical contributions that investigate the impact of environmental regulation on economic performance or "competitiveness" based on specific indicators such as imports or productivity growth The findings of Ederington and Minier (2003) for the U.S. industry suggest that net imports are positively affected by the level of abatement costs used as a proxy for the stringency of environmental regulation: More stringent environmental regulation thus in turn implies higher imports, i.e. a decline in competitiveness. Gray (1987) uses productivity growth as a competitiveness indicator and does not find a significant impact of pollution abatement costs on total factor productivity growth in his cross-sectional analysis for U.S. industries. In contrast, a recent study undertaken by Hamamoto (2006) suggests that pollution control expenditures measured at the industry level for Japan positively affect total factor productivity growth via a stimulation of R\&D investment. Shadbegian and Gray (2005) introduce PACE data into a production function approach at the U.S. plant level for pulp and paper mills, oil refineries, and steel mills. They find that pollution abatement expenditures hardly affect total production but affect negatively the productivity of non-abatement inputs.

All in all, there is no clear empirical answer to the question on economic effects of environmental regulation or expenditures. If positive effects on particular types of innovation (such as environmental innovation) are found, the general economic impacts remain unclear: For example, a stimulating effect of environmental expenditures on environmental innovation could be accompanied by a crowding out of conventional, i.e. non-environmental innovation (cp. Jaffe et al., 1995).

In most studies that assess the interrelationship between environmental and economic performance innovation is used as an indicator of both economic as well as environmental 
performance. Here, a positive effect of environmental management on environmental innovation at the firm level is identified by the bulk of the available studies (e.g. Rennings et al. (2006) for Germany or Frondel et al. (2007) for a set of seven OECD countries). More recently, however, the causal relationship between environmental management and economic performance has been questioned: Seijas-Nogareda and Ziegler (2007) argue rather in favour of a complex dynamic interrelationship between these measures. Also, evidence is fading away if economic performance is proxied more directly, e.g. by financial performance. Ziegler et al. (2007) for Europe and Konar and Cohen (2001) for the U.S. find a positive effect of environmental performance on stock performance. Telle (2006), however, reports contrary results using a Norwegian plant-level panel data set, where he highlights the importance of controlling for unobserved heterogeneity.

Based on a panel data analysis of the German manufacturing industry between 1996 and 2002 set, we try to shed further light on the relationship between economic performance (measured in terms of production growth) on the one hand, and environmental expenditures, regulation and performance on the other hand. The contribution of our paper is twofold: From an empirical point of view, we provide the first econometric analysis for the German manufacturing industry on the productivity effects triggered by environmental (green) investment as well as environmental and energy expenditures. From a methodological perspective, we demonstrate the usefulness of modern panel data techniques that take into account not only unobserved heterogeneity, but also state dependence, i.e. dynamic adjustment of the dependent variable. ${ }^{1}$ Moreover, we take care of possible endogeneity problems - particularly of variables related to environmental regulation and performance (e.g., Seijas-Nogareda and Ziegler, 2007) - by using instrumental variable techniques.

The remainder of this paper is structured as follows: Section 2 briefly summarizes our theoretical production function approach. Section 3 lays out the data and variables employed in our empirical analysis Section 4 deals with methodological details. Section 5 provides the estimation results, section six concludes.

\section{Theoretical Background}

One main argument to avert the environmental regulation aimed at the "greening" of industries is that it will harm the regulated industry in its international competitiveness. Although there is no general definition of competitiveness the reasoning behind this argument is straightforward: Under the simple (but strong) assumption of perfectly competitive markets any onesided binding regulation to a firm will impose additional costs, thereby decreasing the firm's profitability and market share.

Since the notion of competitiveness is not rigorously defined, a less blurry question can be asked about productivity: Will environmental action, i.e. environmental investment or expenditure, render the economy less productive? One can address this issue within a simple production function approach. Let's assume a production function $(F)$ for sector $i(1, \ldots, \mathrm{N})$ at time $t(1, \ldots, \mathrm{T})$ to produce a quantity $(y)$ which depends on the actual inputs $\left(x_{k}\right)$ into the production process as well as on other non-input factors $\left(o_{l}\right)$ such as the macroeconomic, regulatory or market environment:

\footnotetext{
${ }^{1}$ Most of the cited literature on the interaction between environmental and economic performance is based on the application of cross-sectional or static panel data methods.
} 


$$
y_{i, t}=F\left(x_{k, i, t}, o_{l, i, t}\right) \text {. }
$$

The question arises whether all these inputs $x_{k}$ should (or could) be attributed directly to the productive process. Those parts of expenditures that pursue environmental goals may be considered as non-productive input as opposed to capital and labor used for production (Shadbegian and Gray, 2005). In other words, environment-related inputs such as pollution abatement expenditures could be considered rather as an additional output, in this case abatement.

A major challenge then is to identify environment-related inputs (investments or expenditures) and to determine their productivity effects: In principle, cost components may leave productivity unaffected, have a negative impact on productivity or may positively affect productivity (as stated by the famous Porter Hypothesis - see Porter and van der Linde, 1995). Adopting (w.l.o.g.) a simple Cobb-Douglas production function where $x_{1 \ldots j}^{E N V}$ denotes environment-related inputs while $x_{1 \ldots k}^{P R O D}$ and $o_{1 \ldots l}$ refer to other input expenditures and noninput factors, we can phrase production as:

$$
y_{i, t}=\alpha \cdot \prod_{j=1}^{J}\left(x_{j, i, t}^{E N V}\right)^{a_{j}} \cdot \prod_{k=1}^{K}\left(x_{k, i, t}^{P R O D}\right)^{b_{k}} \cdot \prod_{l=1}^{L}\left(o_{l, i, t}\right)^{c_{l}}
$$

Taking the logarithm on both sides and calculating the variation over time yields

$$
\dot{y}_{i, t}=\sum_{j=1}^{J} a_{j} \dot{x}_{j, i, t}^{E N V}+\sum_{k=1}^{K} b_{k} \dot{x}_{k, i, t}^{P R O D}+\sum_{l=1}^{L} c_{l} \dot{o}_{l, i, t} .
$$

In our econometric analysis, the productivity effects of different inputs - including environment-related inputs $x_{1 . . j}^{E N V}$ - are empirically tested.

\section{Data and Variables}

We use a panel data set which includes all 23 sectors of the German manufacturing industry based on the two-digit NACE codes from 1996 to 2002. Monetary data is measured in prices of 1995. In our estimations, we employ log-log specifications. As a proxy for production growth, the dependent variable of our analysis, denoted $\dot{q}$, is the absolute growth of gross value added (GVA). Growth in sectoral GVA represents the change in the value of goods and services produced by an industry, less the value of the respective inputs. The variable has a sample mean of 223.55 Mio. Euro. The explanatory variables of special interest in our panel data analysis are those associated with environmental regulation and performance $\left(x_{1 \ldots j}^{E N V}\right){ }^{2}$ As a German "analogue" to the U.S. Pollution Abatement Costs and Expenditures (PACE) we draw on environmental expenditure (i.e. expenditures for environmental protection associated with a "greener", less polluting production process) of the German manufacturing industry which is reported by the German Federal Statistical Office. The environmental expenditures include expenditures for the operation of "green" facilities as well as expenditures that stem

\footnotetext{
${ }^{2}$ In the literature of production function estimation, it is common to incorporate a capital stock that is built according to a perpetual inventory method (cp. Martin, 2002). Due to our short sample period, such a capital stock construction is not feasible for the present analysis, where we simply use investment and expenditure data.
} 
from non-operational "green" measures such as fees for waste disposal or current costs for environmental protection (expenditures for water protection, air pollution control etc.). With a sample mean of around 400 Mio. Euro per year (see Table 1), the environmental expenditures of the German manufacturing sectors represents only a modest cost share as compared to other categories of expenditure (see Figure 1). In the literature, environmental expenditures are often used as a proxy variable for environmental regulation (see introduction). Obviously, this can be problematic in our case: Apart from expenditures due to legal codes and official sanctions, the German data on environmental expenditures also includes expenditures for voluntary pollution control measures. Such costs do not form part, e.g., of PACE in the U.S. Furthermore, Jaffe et al. (1995) argue that even the PACE may not only give costs of compliance with environmental regulation, but include expenditures that improve the final product or at least the efficiency of the production process at the same time. Therefore, the relationship between environmental expenditures and productivity may only partly reflect regulatory impacts, but rather constitute a combined effect of environmental regulation and voluntary environmental measures. Within our analysis, we consider the energy expenditures of the German manufacturing industry as a further explanatory variable. Energy expenditures include expenditures for combustibles, electricity, gas, and heating. A larger part of energy expenditures are due to energy taxes levied by the German State, thereby reflecting regulatory pressure. On average, energy expenditures make up more than twice the environmental expenditures in our sample (875 Mio. Euro). Alike their environmental counterpart, energy expenditures are quite heterogeneous across sectors and years.

Finally, we employ the investment data on environmental protection as explanatory variable. Environmental investment covers additive or integrated investment that exclusively or at least predominantly aims at reducing the environmental damages of production. In analogy to environmental expenditures, environmental investment does not only incorporate investment that is a response to environmental regulation, but also voluntary "green" investment. Compared to environmental and energy expenditures, environmental investment is small with a sample mean of around 70 Mio. Euro (see Figure 1). There are larger differences in environmental investment across industries: While the sample minimum amounts to 0.03, the maximum ranges above 540 Mio. Euro. The correlation analysis reveals that amongst the environment-related variables, environmental investment correlates most strongly (and positively) with GVA growth (the correlation coefficient is 0.11 - see Table 2).

Figure 1 Selected Expenditure and Investment Figures of the German Manufacturing Industry

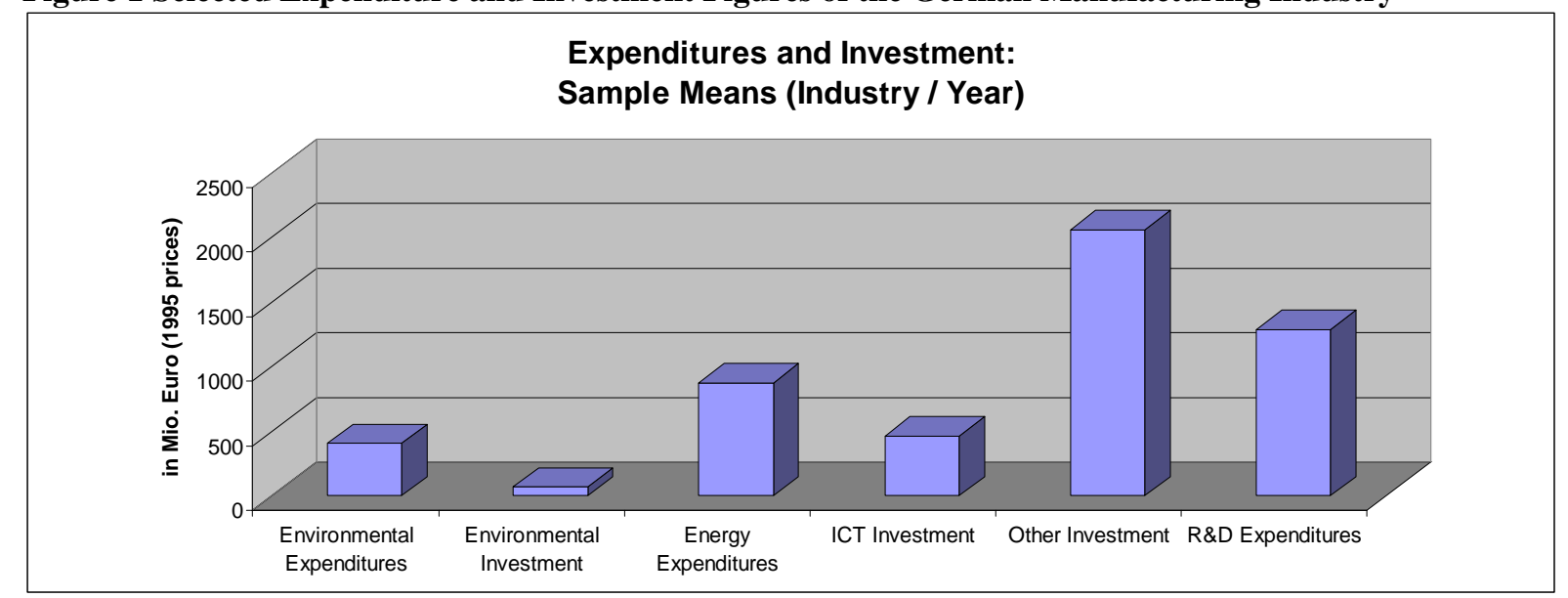

Source: German Federal Statistical Office and OECD

Besides environmental investment, energy expenditures and environmental expenditures, we employ several control variables, $x_{1 \ldots k}^{P R O D}$, for other expenditures and investment. The inclusion 
of such variables is necessary in order to avoid possible omitted variable biases given that correlation among different expenditure- and investment-measures is generally high. In our data set, environmental investment, expenditures and energy expenditures are in fact strongly correlated with other investment and different cost categories (cp. Table 2). Among other expenditures and investment, we account for investment in information and communication technologies (ICT) which is considered as an important driver for sectoral performance and competitiveness (cp. e.g. Jorgenson, 2001). According to our descriptive statistics ICT investment is far higher than environmental investment, with a sample mean of 465 Mio. Euro. Furthermore, we incorporate other investment, i.e. the residual of overall investment minus environmental and ICT investment. On the expenditure side, we include gross salaries (i.e. labor costs) as the most important cost variable of German industries (sample mean: 9490 Mio. Euro) and social security contributions, i.e. the contribution of the employer to the pension fund, unemployment, health, accident, and long term care insurance (sample mean: 2330 Mio. Euro). Moreover, expenditures for research and development (sample mean; 1300 Mio. Euro) are taken into account as a potential productivity driver (Guellec and van Pottelsberghe, 2001).

Besides capital inputs such as expenditures and investment, human capital inputs are also relevant for production. We therefore consider labor inputs measured in terms of hours worked (sample mean: 2.7 Mio. hours per sector and year). Besides the quantity, the quality of labor may play an important role for productivity growth (Redding, 1996). We capture the quality of labor through the share of white-collar employees in each sector which ranges between 23 and 69 per cent of total employees (mean: 38 per cent). Finally, we consider other non-input factors $o_{1 \ldots l}$, in particular the intensity of competition. The latter is measured with the Herfindahl-Hirschmann Index $(\mathrm{HHI})^{3}$ and the turnover-rate (the share of entering and exiting firms in the total number of firms within an industry). Both variables are included following the hypothesis that highly competitive industries may exhibit a higher performance than less competitive ones (Nalebuff and Stiglitz, 1983). All data used in this analysis stems from databases of the German Federal Statistical Office and is publicly available free of charge. An exception is the data on ICT investment that is taken from OECD databases.

\section{Methodology}

For our econometric analysis, we can build on panel data which offers important advantages vis-à-vis pure time series data or cross-sectional data approaches. Generally, the use of panel data in comparison with both time series and cross-sectional data augments the number of observations that can be evaluated within an econometric analysis. Moreover, it allows for controlling for heterogeneity over sectors (more generally entities) and time as well as for dynamic adjustment processes. ${ }^{4}$

Production growth may be characterized by both time- and industry-specific effects with unobserved time-invariant heterogeneity over the sectors being due to, e.g., sector-specific technologies. The respective estimation approach then reads as

${ }^{3}$ The HHI is calculated as $H H I_{i, t}=\frac{1000}{A_{n, t}^{2}} \times \sum_{k=1}^{n} a_{k, t}^{2}$, with $a_{k, t}$ being the market share of firm $k$ within the

respective sector $i$ at time $t$, and $A_{n, t}=\sum_{k=1}^{n} a_{k, t}$.

${ }^{4}$ For overviews on panel data estimation see e.g. Arellano (2003) and Bond (2002). 


$$
y_{i, t}-y_{i, t-1}=\beta^{\prime} x_{i, t}+t_{t}+u_{i}+\varepsilon_{i, t} \text {, with } \varepsilon_{i, t} \sim\left(0, \sigma^{2}\right), i=1,2, \ldots, N, t=1,2, \ldots, T,
$$

where $y_{i, t}$ denotes production for industry $i$ in period $t, x_{i, t}$ reflects a vector of all current or lagged values of explanatory variables of the same industry, $t_{t}$ is a time-specific effect common for all sectors, $u_{i}$ is an unobserved industry-specific time-invariant effect, and $\varepsilon_{i, t}$ is a disturbance term that is independent and identically distributed across industries $i=1,2, \ldots, N$ and over time $t=1,2, \ldots, T$.

The standard ordinary least squares (OLS) estimation of the parameter vector $\beta$ which does not account for time- and industry-specific heterogeneity present in the dependent variable leads to (at least) inefficient results. In case that such time or individual effects correlate with the explanatory variables, OLS is even inconsistent. ${ }^{5}$ Therefore, we augment the model by dummy variables for both the time and industry dimension. The resulting model corresponds to the Least Squares Dummy Variable estimator (LSDV) for production growth with both industry- and time-specific effects. ${ }^{6}$ Another problem may arise if there is state dependence in present the dependent variable on top of the phenomenon of unobserved industry-specific time-invariant effects, i.e.:

$$
\begin{aligned}
& y_{i, t}-y_{i, t-1}=\gamma\left(y_{i, t-1}-y_{i, t-2}\right)+\beta^{\prime} x_{i, t}+t_{t}+u_{i}+\varepsilon_{i, t}, \quad \text { with } \quad \varepsilon_{i, t} \sim\left(0, \sigma^{2}\right), \quad i=1,2, \ldots, N, \\
& t=1,2, \ldots, T .
\end{aligned}
$$

Even the LSDV gives inconsistent parameter estimates if applied to such a dynamic model: For panels where the number of time periods is small (as in our case with $T=6$ ), mean deviation induces correlation between the lagged dependent variable and the error term leading to biased parameter estimates (so-called "Nickell-bias", Nickell, 1981). ${ }^{7}$ Neglection of existing state dependence, however, would again result in a misspecification of the empirical model. We therefore need an approach that accounts for both, unobserved heterogeneity and state dependence. Against this background, we make use of a (Nickell) bias corrected LSDV estimator (LSDVC; Bruno, 2005) where results from a consistent estimator deliver the initial values (a bootstrap variance-covariance matrix is calculated). Furthermore, we apply instrumental variable technique in order to solve the problem of the Nickell-bias. The basis for such approach is provided by Anderson and Hsiao $(1981,1982)$ who propose a Two Stage Least Squares estimator for the first-differenced $A R(1)$ panel data model (2SLS DIF; formulated with time effects here):

$$
\begin{aligned}
& y_{i, t}-y_{i, t-1}=\beta^{\prime}\left(x_{i, t}-x_{i, t-1}\right)+\gamma\left(y_{i, t-1}-y_{i, t-2}\right)+t_{t}+\left(\varepsilon_{i, t}-\varepsilon_{i, t-1}\right), \quad \text { with } \varepsilon_{i, t} \sim\left(0, \sigma^{2}\right), \\
& i=1,2, \ldots, N, t=1,2, \ldots, T .
\end{aligned}
$$

In contrast to industry dummies (or, alternatively, deviations from group means) used by the LSDV, first differences eliminate unobserved sector heterogeneity. This approach yields consistent parameter estimates when lagged levels $y_{i, t-2}$ are uncorrelated with $\left(\varepsilon_{i, t}-\varepsilon_{i, t-1}\right)$ and are used as an instrumental variable for equation (6). The parameter $\gamma$ denotes the effect of the

\footnotetext{
${ }^{5}$ Note that production growth as the first difference GVA already excludes time-invariant industry-specific effects that could be present in GVA levels.

${ }^{6}$ The use of dummy variables at the industry dimension in order to eliminate unobserved heterogeneity over industries ui is equivalent to using mean-differentiated variables.

${ }^{7}$ Note that the Nickell-bias does not even vanish in samples with a high number of industries.
} 
lagged dependent variable while the parameter vector $\beta$ measures the effect of the other explanatory variables. For endogenous $x$ 's, lagged levels besides other exogenous variables are available as instruments. Environmental, ICT and other investment, environmental, energy, r\&d expenditures, social security contributions, gross salaries and hours worked at the sectoral level may not only affect production growth, but may also be caused by the magnitude of production growth of the same period. Possible reverse causality problems may be avoided using instrumental variable techniques to equation (6). ${ }^{8}$ If the panel does have more than three time series observations (as in our case), the model is overidentified because there are even more lagged levels available as instruments. It will then be beneficial to make use of the dynamic panel data estimator (GMM DIF) developed by Arellano and Bond (1991), instead of the 2SLS DIF. The GMM DIF is based on the same first-difference transformation as shown in equation (6). However, asymptotically efficient parameter estimates are obtained from a Generalized Method of Moments (GMM) framework which uses a weighting procedure for the instrument matrix. This approach also allows for the instrumentation of endogenous $x$ 's. However, the properties of the GMM DIF (as well as those of the 2SLS DIF) hinge on the number on entities (here: sectors) covered by the sample (cp. e.g. Kiviet, 1995). According to Bruno (2005), the LSDVC could be beneficial in comparison with the GMM DIF for small samples such as in our case $N=23$. In our empirical analysis, we apply OLS, LSDV, LSDVC, and GMM DIF. This serves as an important robustness check and increases transparency of our analysis.

\section{Results}

For all of the four estimation techniques, we report one specification including all explanatory variables, and another one including only the environment- and energy-related variables plus all other explanatory variables that show statistical significance at least at the $10 \%$-level.

For industry panel settings only little confidence is attributed to simple OLS estimation results due to the prevailing sources of bias outlined in previous section. Since production growth as our dependent variable is already the first difference of overall production (GVA), an OLS approach may not perform that bad: sector-specific differences in GVA itself are eliminated in taking first differences. The commonly adopted, more elaborate technique for our problem class, however, is a LSDV estimator which controls for both industry- and time-specific effects. ${ }^{9}$ When lagged production growth as an explanatory variable enters into the estimated equation, a dynamic panel approach seems to be more adequate for our setting: The 2SLS DIF estimator yields unbiased parameter estimates, but in contrast to the GMM DIF (which we apply) it is not asymptotically efficient given our time series dimension with $T=6$. Moreover, the LSDVC, which however does not allow for the solution of any endogeneity problem, is applied. For the GMM DIF, none of the diagnostic tests (on first- and second order serial correlation in the residuals as well as the Sargan test on overidentifying restrictions) indicates a misspecification. Furthermore, in this approach we instrument all investment, expenditure and employment variables ${ }^{10}$ in order to eliminate possible reverse causality problems. According to specification tests of the first stage regressions, the lags of

\footnotetext{
${ }^{8}$ Instrumental variable technique for the LSDVC, in contrast, has not yet been developed.

${ }^{9}$ The results of an F-Test for industry-specific effects in the LSDV do not suggest, however, that such effects (in contrast to time-specific effects) are already eliminated by taking first differences of GVA in order to generate GVA growth (F-statistic of 0.79 and 1.07, respectively). Therefore, both OLS with GVA growth as dependent variable and the GMM DIF should not suffer from specification problems due to omitted industry dummy variables.

${ }^{10}$ I.e. the variables environmental, ICT and other investment, environmental, energy, R\&D, social security contributions, gross salaries and hours worked.
} 
both first as well as second applied as instruments explain significantly the endogenous variables (see Table 4 in the appendix).

Concerning the explanatory variables of major interest, our results show robustness over all four estimation techniques. For the expenditure figures that are related to energy and the environment, we find only weak evidence for a contribution to production growth of the respective sector. This is especially the case for energy expenditures: OLS, LSDV as well as dynamic panel data approaches using the LSDVC and GMM DIF (see Table 3) show very small values for the estimated coefficient of energy expenditures which - with the exception of OLS - do not significantly differ from zero. Our estimation results thus do not suggest a significant impact of energy expenditures on production growth in the German manufacturing industry.

The results for environmental expenditures are somewhat different: While our our estimations predominantly yield very small coefficients (partly lacking significance), the LSDV as well as the LSDVC provide significant and positive impacts. The - statistically significant difference between these LSDV/LSDVC results and the results from the GMM DIF which do not suggest statistical significance of the estimated environmental expenditures parameter might be due to possible endogeneity or reverse causality of the environmental expenditures in our setting: If sectors with higher production growth augment their environmental expenditures, the LSDV and LSDVC (besides OLS) would yield upward biased parameter estimates for this variable (in contrast to the GMM DIF). Since our estimation results go along with such an explanation, endogeneity of the environmental expenditures is plausible and the GMM DIF seems to give the more credible results.

Environmental investment stands out as the only variable with robust positive implications for production growth. Across all estimation techniques, there is a positive and statistically significant impact of environmental investment on production growth. In contrast to environmental expenditures, this effect does not seem to be endogenously driven by production growth itself, as GMM DIF results do not significantly differ from the results of other estimation techniques that do not control for such possible endogeneity.

In line with the existing literature, we find a positive impact of ICT investment on production growth. According to our results (except for simple OLS), this effect is much - and significantly from a statistical point of view - stronger than for its environmental counterpart. As far as other investment is concerned, however, we obtain quite robust empirical evidence for a negative (small) effect on production growth.

For expenditures that are not related to energy and the environment - such as $R \& D$ expenditures, social security contributions, and gross salaries - we do not find empirical evidence for a statistically significant impact on production growth. The same holds for the Herfindahl-Hirschmann Index (HHI) and the turnover-rate, both employed as variables to control for a possible impact of competition intensity. In contrast, labor positively contributes to production growth (GMM DIF results) - the coefficients of both hours worked and quality of labor significantly enter the estimated equation.

\section{Conclusions}

In this paper, we have analyzed the effect of environmental expenditures, energy expenditures and as well as environmental investment on production growth. Our empirical analysis is 
based on a production function framework applied to a panel dataset of the German manufacturing industry between 1996 and 2002. Our econometric analysis is based on modern panel data techniques that allow for unobserved heterogeneity over industries and time as well as for lagged adjustment processes of production growth. Furthermore, we take into account possible endogeneity of the explanatory variables making use of their lagged values as instrumental variables.

Our estimations indicate that both environmental and energy expenditures do no affect production growth in German manufacturing industries. Controlling for possible endogeneity of explanatory variables proves to be useful especially concerning the relationship between environmental expenditures and production growth: Our estimation results suggest that environmental expenditures are endogenous - techniques not taking into account such endogeneity yield a positive effect which in reality may stem from a reverse (positive) effect of production growth on these expenditures. In contrast, environmental investment robustly exhibits a positive impact which is however substantially lower than that of ICT investment. The latter finding should not be construed as support for the Porter Hypothesis, stating that environmental regulation spurs competitiveness or likewise competitiveness of the regulated industries. Environmental investment may not necessarily be driven by regulation, but simply indicate voluntary environmental performance of the respective industry. With this view, our results suggest that sectors increasing environmental performance via investment instead of expenditure activities benefit in terms of productivity growth.

While our analysis is no direct evaluation of environmental regulation, it contributes to the empirical assessment of the economic consequences triggered by environmental policy: In order to be compatible with economic goals such as the stimulation of productivity, environmental regulation should rather encourage investment than solely causing additional costs. According to economic theory, this is the case for market based policy instruments that provide more incentives for investment and technological change than command and control measures (Requate, 2005).

Regarding future research, it would be interesting to analyse whether our results also hold for countries other than Germany. Furthermore, as soon as firm-level data becomes available, analysis at the micro level could be insightful. 


\section{References}

Anderson, T.W. and C. Hsiao (1981), Estimation of Dynamic Models with Error Components, Journal of the American Statistical Association 76, 598-606.

Anderson, T.W. and C. Hsiao (1982), Formulation and Estimation of Dynamic Models Using Panel Data, Journal of Econometrics 18: 47-82.

Arellano, M. (2003), Panel Data Econometrics, Oxford: Oxford University Press.

Arellano, M. and S.R. Bond (1991), Some Tests of Specification for Panel Data: Monte Carlo Evidence and an Application to Employment Equations, Review of Economic Studies 58, 277297.

Bond, S.R. (2002), Dynamic Panel Data Models: A Guide to Micro Data Methods and Practice, Portuguese Economic Journal 1, 141-162.

Brunnermeier, S.B. and M.A. Cohen (2003), Determinants of Environmental Innovation in US Manufacturing Industries, Journal of Environmental Economics and Management 45, 278-293.

Bruno, G.S.F. (2005), Approximating the Bias of the LSDV Estimator for Dynamic Unbalanced Panel Data Models, Economics Letters 87, 361-366.

Czarnitzki, D. and K. Kraft (forthcoming), On the Profitability of Innovative Assets, Applied Economics.

Ederington, J. and J. Minier (2003), Is Environmental Policy a Secondary Trade Barrier? An Empirical Analysis, Canadian Journal of Economics 36, 137-154.

Frondel, M., J. Horbach, and K. Rennings (2007), End-of-Pipe or Cleaner Production? An Empirical Comparison of Environmental Innovation Decisions across OECD Countries, Business Strategy and the Environment 16, 571-584.

Gray, W.B. (1987), The Cost of Regulation: OSHA, EPA and the Productivity Slowdown, American Economic Review 77, 998-1006.

Guellec, D. and B. van Pottelsberghe de la Potterie (2001), R\&D and Productivity Growth: Panel Data Analysis of 16 OECD Countries, OECD Economic Studies 33, 103-126.

Hamamoto, M. (2006), Environmental Regulation and the Productivity of Japanese Manufacturing Industries, Resource and Energy Economics 28, 299-312.

Jaffe, A.B. and K. Palmer (1997), Environmental Regulation and Innovation: A Panel Data Study, Review of Economics and Statistics 79, 610-619.

Jaffe, A.B., S.R. Peterson, P.R. Portney, and R.N. Stavins (1995), Environmental Regulation and the Competitiveness of U.S. Manufacturing: What Does the Evidence Tell Us? Journal of Economic Literature 33, 132-163. 
Jorgenson, D.W. (2001), Information Technology and the U.S. Economy, American Economic Review 91, 1-32.

Kiviet, J.F. (1995), On Bias, Inconsistency and Efficiency of Various Estimators in Dynamic Panel Data Models, Journal of Econometrics 68, 53-78.

Konar, S. and M.A. Cohen (2001), Does the Market Value Environmental Performance?, Review of Economics and Statistics 83, 281-289.

Lanjouw, J.O. and A. Mody (1996), Innovation and the International Diffusion of Environmentally Responsive Technology, Research Policy 25, 549-571.

Martin, R. (2002), Building the Capital Stock, Centre for Research into Business Activity, mimeo, London.

Nalebuff, B. and J. Stiglitz (1983), Information, Competition and Markets, American Economic Review 73, 278-283.

Nickell, S. (1981), Biases in Dynamic Models with Fixed Effects, Econometrica 49, 14171426.

OECD and Eurostat (1997), Oslo Manual: Proposed Guidelines for Collecting and Interpreting Technological Innovation Data, Organization for Economic Co-Operation and Development: Paris.

Palmer, K., W.E. Oates, and P.R. Portney (1995), Tightening Environmental Standards: The Benefit-Cost or the No-Cost Paradigm? Journal of Economic Perspectives 9, 119-132.

Pickman, H. (1998), The Effect of Environmental Regulation on Environmental Innovation, Business Strategy and the Environment 7, 223-233.

Porter, M. and C. van der Linde (1995), Toward a New Conception of the EnvironmentCompetitiveness Relationship, Journal of Economic Perspectives 9, 97-118.

Redding, S. (1996), The Low-Skill, Low-Quality Trap: Strategic Complementarities between Human Capital and R\&D, Economic Journal 106, 458-470.

Rennings, K., A. Ziegler, K. Ankele, and E. Hoffmann (2006), The Influence of Different Characteristics of the EU Environmental Management and Auditing Scheme on Technical Environmental Innovations and Economic Performance, Ecological Economics 57, 45-59.

Requate, T. (2005), Dynamic Incentives by Environmental Policy Instruments - A Survey, Ecological Economics 54, 175-195.

Seijas Nogareda, J. and A. Ziegler (2006), Green Management and Green Technology? Exploring the Causal Relationship, ZEW Discussion Paper No. 06-040, Mannheim.

Shadbegian, R.J. and W.B. Gray (2005), Pollution Abatement Expenditures and Plant-Level Productivity: A Production Function Approach, Ecological Economics 54, 196-208. 
Telle, K. (2006), "It Pays to be Green" - A Premature Conclusion? Environmental and Resource Economics 35, 195-220.

Ziegler, A., M. Schröder und K. Rennings (2007), The Effect of Environmental and Social Performance on the Stock Performance of European Corporations, Environmental and Resource Economics 37, 661-680. 


\section{Appendix}

Table 1 Descriptive Statistics Dataset

\begin{tabular}{|c|c|c|c|c|c|}
\hline Variable & Mean & Std. Dev. & Min. & Max. & Obs. \\
\hline $\begin{array}{r}\text { Environmental } \\
\text { Expenditures }\end{array}$ & 399.92 & 630.59 & 6.67 & 3450.28 & 161 \\
\hline $\begin{array}{r}\text { Environmental } \\
\text { Investment }\end{array}$ & 66.65 & 92.86 & 0.03 & 544.02 & 161 \\
\hline $\begin{array}{r}\text { Energy } \\
\text { Expenditures }\end{array}$ & 874.43 & 1052.88 & 24.36 & 4101.92 & 161 \\
\hline $\begin{array}{r}\text { ICT } \\
\text { Investment }\end{array}$ & 464.58 & 427.58 & 6.26 & 1916.18 & 161 \\
\hline $\begin{array}{r}\text { Other } \\
\text { Investment }\end{array}$ & 2058.89 & 2204.23 & 56.47 & 11143.12 & 161 \\
\hline $\begin{array}{r}R \& D \\
\text { Expenditures }\end{array}$ & 1288.44 & 2194.17 & 2.82 & 10823.03 & 161 \\
\hline Gross Salaries & 9491.03 & 9707.89 & 183.73 & 37619.31 & 161 \\
\hline $\begin{array}{r}\text { Social } \\
\text { Security } \\
\text { Contributions } \\
\end{array}$ & 2328.93 & 2425.38 & 41.95 & 10508.29 & 161 \\
\hline$H H I$ & 50.01 & 72.21 & 1.44 & 266.48 & 161 \\
\hline Turnover & 0.18 & 0.11 & 0.05 & 0.92 & 161 \\
\hline Hours Worked & 267189.70 & 252448.10 & 10151.00 & 943605.00 & 161 \\
\hline $\begin{array}{r}\text { Quality of } \\
\text { Labor }\end{array}$ & 0.38 & 0.12 & 0.23 & 0.69 & 161 \\
\hline $\begin{array}{r}\text { Gross Value } \\
\text { Added }\end{array}$ & 17046.89 & 15316.99 & 490.00 & 57510.00 & 161 \\
\hline $\begin{array}{r}\text { Gross Value } \\
\text { Added Growth }\end{array}$ & 223.55 & 1527.92 & -4600.00 & 8060.00 & 138 \\
\hline
\end{tabular}

Note: All monetary data is given in Mio. Euro and is measured in 1995 prices. 


\begin{tabular}{|c|c|c|c|c|c|c|c|c|c|c|c|c|c|c|}
\hline & $\begin{array}{l}\text { Environ- } \\
\text { mental } \\
\text { Expendi- } \\
\text { tures } \\
\end{array}$ & $\begin{array}{l}\text { Environ- } \\
\text { mental } \\
\text { Investment }\end{array}$ & \begin{tabular}{|l} 
Energy \\
Expendi- \\
tures
\end{tabular} & $\begin{array}{l}\text { ICT } \\
\text { Investment }\end{array}$ & $\begin{array}{l}\text { Other } \\
\text { Investment }\end{array}$ & $\begin{array}{l}\text { R\&D } \\
\text { Spending }\end{array}$ & \begin{tabular}{|l} 
Gross \\
Salaries
\end{tabular} & $\begin{array}{l}\text { Social Sec. } \\
\text { Contribu- } \\
\text { tions }\end{array}$ & HHI & Turnover & $\begin{array}{l}\text { Hours } \\
\text { Worked }\end{array}$ & $\begin{array}{l}\text { Quality of } \\
\text { Labor }\end{array}$ & $\begin{array}{l}\text { Gross } \\
\text { Value } \\
\text { Added }\end{array}$ & $\begin{array}{l}\text { Gross } \\
\text { Value } \\
\text { Added } \\
\text { Growth } \\
\end{array}$ \\
\hline $\begin{array}{l}\text { Environmental } \\
\text { Expenditures }\end{array}$ & 1.00 & & & & & & & & & & & & & \\
\hline $\begin{array}{l}\text { Environmental } \\
\text { Investment }\end{array}$ & 0.94 & 1.00 & & & & & & & & & & & & \\
\hline Energy Expenditures & 0.87 & 0.79 & 1.00 & & & & & & & & & & & \\
\hline ICT Investment & 0.49 & 0.54 & 0.50 & 1.00 & & & & & & & & & & \\
\hline Other Investment & 0.59 & 0.61 & 0.63 & 0.83 & 1.00 & & & & & & & & & \\
\hline R\&D Spending & 0.46 & 0.47 & 0.38 & 0.65 & 0.84 & 1.00 & & & & & & & & \\
\hline Gross Salaries & 0.39 & 0.40 & 0.48 & 0.91 & 0.88 & 0.72 & 1.00 & & & & & & & \\
\hline $\begin{array}{l}\text { Social Security } \\
\text { Contributions }\end{array}$ & 0.45 & 0.46 & 0.52 & 0.91 & 0.91 & 0.77 & 0.99 & 1.00 & & & & & & \\
\hline HHI & -0.38 & -0.05 & -0.25 & 0.03 & -0.09 & 0.05 & -0.12 & -0.09 & 1.00 & & & & & \\
\hline Turnover & -0.22 & -0.12 & -0.20 & -0.17 & -0.20 & -0.15 & -0.16 & -0.16 & -0.08 & 1.00 & & & & \\
\hline Hours Worked & 0.92 & 0.31 & 0.47 & 0.83 & 0.81 & 0.54 & 0.94 & 0.91 & -0.25 & -0.17 & 1.00 & & & \\
\hline Quality of Labor & 0.13 & 0.10 & -0.14 & 0.09 & -0.07 & 0.10 & -0.06 & -0.05 & 0.41 & -0.09 & -0.27 & 1.00 & & \\
\hline Gross Value Added & 0.68 & 0.68 & 0.82 & 0.87 & 0.95 & 0.75 & 0.98 & 0.98 & -0.38 & -0.22 & 0.92 & 0.05 & 1.00 & \\
\hline $\begin{array}{l}\text { Gross Value Added } \\
\text { Growth }\end{array}$ & 0.07 & 0.11 & -0.06 & -0.04 & -0.10 & -0.02 & -0.15 & -0.13 & 0.23 & 0.13 & -0.19 & 0.09 & -0.07 & 1.00 \\
\hline
\end{tabular}

Notes: 138 observations. All variables are in logs. 
Table 3 Estimation Results

\begin{tabular}{|c|c|c|c|c|c|c|c|c|}
\hline $\begin{array}{l}\text { Gross Value Added } \\
\text { Growth }\end{array}$ & OLS & OLS & $\begin{array}{l}\text { LSDV with time } \\
\text { (year) dummies }\end{array}$ & $\begin{array}{l}\text { LSDV with time } \\
\text { (year) dummies }\end{array}$ & $\begin{array}{l}\begin{array}{l}\text { LSDVC with time } \\
\text { (year) dummies }\end{array} \\
\end{array}$ & \begin{tabular}{|l}
$\begin{array}{l}\text { LSDVC with time } \\
\text { (year) dummies }\end{array}$ \\
\end{tabular} & $\begin{array}{l}\text { GMM DIF with time } \\
\text { (year) dummies }\end{array}$ & \begin{tabular}{|l} 
GMM DIF with time \\
(year) dummies
\end{tabular} \\
\hline $\begin{array}{l}\text { Environmental } \\
\text { Expenditures }\end{array}$ & \begin{tabular}{|l|}
0.04 \\
$(0.03)$
\end{tabular} & \begin{tabular}{|l|}
0.06 \\
$(0.05)$
\end{tabular} & \begin{tabular}{|l|}
$0.23^{* *}$ \\
$(0.11)$ \\
\end{tabular} & \begin{tabular}{|l|}
$0.31 * * *$ \\
$(0.09)$
\end{tabular} & \begin{tabular}{|l|}
0.20 \\
$(0.13)$
\end{tabular} & \begin{tabular}{|l|}
$0.24^{* *}$ \\
$(0.11)$
\end{tabular} & \begin{tabular}{|l|}
0.00 \\
$(0.10)$ \\
\end{tabular} & \begin{tabular}{|l|}
0.02 \\
$(0.12)$ \\
\end{tabular} \\
\hline $\begin{array}{l}\text { Environmental } \\
\text { Investment }\end{array}$ & \begin{tabular}{|l|}
0.06 \\
$(0.04)$
\end{tabular} & $\begin{array}{l}0.03^{* *} \\
(0.02)\end{array}$ & \begin{tabular}{|l|}
$0.07 *$ \\
$(0.04)$
\end{tabular} & $\begin{array}{l}0.07^{* *} \\
(0.03)\end{array}$ & \begin{tabular}{|l|}
0.05 \\
$(0.04)$
\end{tabular} & \begin{tabular}{|l|}
$0.05^{*}$ \\
$(0.03)$
\end{tabular} & $\begin{array}{l}0.06^{* *} \\
(0.02)\end{array}$ & $\begin{array}{l}0.06^{* *} \\
(0.03)\end{array}$ \\
\hline Energy Expenditures & \begin{tabular}{|l|}
-0.04 \\
$(0.03)$
\end{tabular} & \begin{tabular}{|l}
$-0.11 * *$ \\
$(0.05)$
\end{tabular} & $\begin{array}{l}-0.02 \\
(0.12)\end{array}$ & $\begin{array}{l}-0.07 \\
(0.11)\end{array}$ & \begin{tabular}{|l|}
0.03 \\
$(0.14)$
\end{tabular} & \begin{tabular}{|l|}
0.01 \\
$(0.12)$
\end{tabular} & $\begin{array}{l}0.05 \\
(0.08)\end{array}$ & \begin{tabular}{|l|}
0.03 \\
$(0.08)$
\end{tabular} \\
\hline ICT Investment & \begin{tabular}{|l|}
0.12 \\
$(0.08)$
\end{tabular} & - & $\begin{array}{l}0.52^{* *} \\
(0.24)\end{array}$ & - & $\begin{array}{l}1.08^{* * *} \\
(0.29)\end{array}$ & $\begin{array}{l}1.08^{* * *} \\
(0.27)\end{array}$ & \begin{tabular}{|l}
$1.36^{* * *}$ \\
$(0.37)$
\end{tabular} & $\begin{array}{l}1.29 * * * \\
(0.33)\end{array}$ \\
\hline Other Investment & \begin{tabular}{|l|}
-0.12 \\
$(0.12)$
\end{tabular} & - & \begin{tabular}{|l}
$-0.20^{* *}$ \\
$(0.08)$
\end{tabular} & \begin{tabular}{|l}
$-0.18^{* * *}$ \\
$(0.07)$
\end{tabular} & \begin{tabular}{|l}
$-0.20^{* *}$ \\
$(0.09)$
\end{tabular} & \begin{tabular}{|l}
$-0.16^{* *}$ \\
$(0.08)$
\end{tabular} & \begin{tabular}{|l}
$-0.23 * * *$ \\
$(0.08)$
\end{tabular} & \begin{tabular}{|l|}
$-0.23^{*}$ \\
$(0.09)$
\end{tabular} \\
\hline$R \& D$ Expenditures & \begin{tabular}{|l|}
$0.02^{* *}$ \\
$(0.01)$
\end{tabular} & - & $\begin{array}{l}-0.00 \\
(0.10)\end{array}$ & - & $\begin{array}{l}-0.01 \\
(0.11)\end{array}$ & - & - & - \\
\hline Gross Salaries & \begin{tabular}{|l|}
$0.56^{*}$ \\
$(0.31)$
\end{tabular} & - & \begin{tabular}{|l|}
-0.22 \\
$(0.57)$
\end{tabular} & - & $\begin{array}{l}-0.57 \\
(0.73)\end{array}$ & \begin{tabular}{|l}
$-1.02 * *$ \\
$(0.50)$
\end{tabular} & \begin{tabular}{|l|}
-0.42 \\
$(0.43)$
\end{tabular} & - \\
\hline $\begin{array}{l}\text { Social Security } \\
\text { Contributions }\end{array}$ & $\begin{array}{l}-0.50^{*} \\
(0.29)\end{array}$ & - & $\begin{array}{l}-0.59^{*} \\
(0.36)\end{array}$ & - & \begin{tabular}{|l|}
-0.49 \\
$(0.37)$
\end{tabular} & - & \begin{tabular}{|l|}
-0.55 \\
$(0.45)$
\end{tabular} & \begin{tabular}{|l}
$-0.63^{*}$ \\
$(0.37)$
\end{tabular} \\
\hline HHI & \begin{tabular}{|l|}
0.02 \\
$(0.01)$
\end{tabular} & - & \begin{tabular}{|l|}
0.06 \\
$(0.09)$
\end{tabular} & - & \begin{tabular}{|l|}
-0.01 \\
$(0.09)$ \\
\end{tabular} & - & \begin{tabular}{|l|l|}
0.08 \\
$(0.08)$ \\
\end{tabular} & - \\
\hline Turnover & \begin{tabular}{|l|}
$0.06^{*}$ \\
$(0.03)$
\end{tabular} & - & \begin{tabular}{|l|}
0.10 \\
$(0.12)$
\end{tabular} & - & \begin{tabular}{|l}
$-67.48^{* *}$ \\
$(31.55)$
\end{tabular} & - & \begin{tabular}{|l|}
0.02 \\
$(0.09)$
\end{tabular} & - \\
\hline Hours Worked & \begin{tabular}{|l|}
-0.04 \\
$(0.07)$
\end{tabular} & - & \begin{tabular}{|l|}
0.38 \\
$(0.46)$
\end{tabular} & - & \begin{tabular}{|l|}
-0.07 \\
$(0.15)$
\end{tabular} & - & \begin{tabular}{|l|}
$0.66^{* *}$ \\
$(0.30)$
\end{tabular} & \begin{tabular}{|l|}
$0.42 *$ \\
$(0.22)$
\end{tabular} \\
\hline Quality of Labor & \begin{tabular}{|l|}
-0.04 \\
$(0.07)$
\end{tabular} & - & \begin{tabular}{|l|}
0.49 \\
$(0.70)$
\end{tabular} & - & \begin{tabular}{|l|}
0.37 \\
$(0.73)$
\end{tabular} & - & \begin{tabular}{|l}
$0.91 * *$ \\
$(0.44)$
\end{tabular} & $\begin{array}{l}0.69 * \\
(0.38)\end{array}$ \\
\hline $\begin{array}{l}\text { Gross Value Added } \\
\text { Growth (t-1) }\end{array}$ & - & - & - & - & \begin{tabular}{|l|}
$-0.43^{* * * *}$ \\
$(0.08)$
\end{tabular} & \begin{tabular}{|l}
$-0.45 * * *$ \\
$(0.08)$
\end{tabular} & $\begin{array}{l}0.21 * * \\
(0.11)\end{array}$ & $\begin{array}{l}0.21^{* *} \\
(0.10)\end{array}$ \\
\hline Constant Term & \begin{tabular}{|l|}
-0.02 \\
$(0.51)$
\end{tabular} & \begin{tabular}{|l|}
$0.26^{* * * *}$ \\
$(0.08)$
\end{tabular} & \begin{tabular}{|l|}
-0.56 \\
$(3.25)$
\end{tabular} & \begin{tabular}{|l|}
-0.08 \\
$(0.75)$
\end{tabular} & - & - & \begin{tabular}{|l|}
1.27 \\
$(1.88)$
\end{tabular} & \begin{tabular}{|l|}
1.59 \\
$(2.03)$
\end{tabular} \\
\hline $\begin{array}{l}\text { No. Obs. } \\
\text { R-sq. } \\
\text { F-Test } \\
\text { Wald-Test } \\
\text { m1 } \\
\text { m2 } \\
\text { Sargan }\end{array}$ & \begin{tabular}{|l|}
138 \\
0.24 \\
1.51 \\
- \\
-1.35 \\
-0.67 \\
- \\
\end{tabular} & \begin{tabular}{|l|}
138 \\
0.22 \\
$2.40 * *$ \\
- \\
-1.13 \\
-0.70 \\
- \\
\end{tabular} & \begin{tabular}{|l|}
138 \\
0.31 \\
$2.64 * * *$ \\
- \\
- \\
- \\
- \\
\end{tabular} & \begin{tabular}{|l|}
138 \\
0.25 \\
$4.34^{* * *}$ \\
- \\
- \\
- \\
- \\
\end{tabular} & $\begin{array}{l}115 \\
- \\
- \\
- \\
- \\
- \\
- \\
\end{array}$ & $\begin{array}{l}115 \\
- \\
- \\
- \\
- \\
- \\
- \\
\end{array}$ & \begin{tabular}{|l|}
115 \\
- \\
- \\
$15132.94 * * *$ \\
$-2.16 * *$ \\
-0.49 \\
91.85 \\
\end{tabular} & \begin{tabular}{|l|}
115 \\
- \\
- \\
$2631.96 * * *$ \\
$-2.16 * *$ \\
0.01 \\
94.13 \\
\end{tabular} \\
\hline
\end{tabular}

Notes: Huber-White robust standard errors in brackets (std. errors of LSDVC based on bootstrapping procedure). *** and *** show significance at the $10 \%-, 5 \%-$, and $1 \%$-level, respectively. All estimations include time

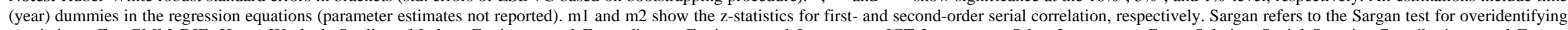
restrictions. For GMM DIF, Hours Worked, Quality of Labor, Environmental Expenditures, Environmental Investment, ICT Investment, Other Investment, Gross Salaries, Social Security Contributions, and Energy Expenditures are treated instrumented with lagged levels. 
Table 4 First Stage Regressions

\begin{tabular}{|l|l|l|l|}
\hline Dep. Var. & $\begin{array}{l}\text { Environmental } \\
\text { Expenditures }\end{array}$ & $\begin{array}{l}\text { Environmental } \\
\text { Investment }\end{array}$ & Energy Expenditures \\
\hline F-Test & $3.37^{* * *}$ & $2.68^{* * *}$ & $3.46^{* * *}$ \\
\hline
\end{tabular}

Notes: Regressions using the first, or first and second lags of Hours Worked, Quality of Labor, Environmental Expenditures, Environmental Investment, ICT Investment, R\&D Spending, Other Investment, Gross Salaries, Social Security Contributions, and Energy Expenditures (besides the regular alternative explanatory variables of the second stage regressions) as explanatory variables. *, ** and *** show significance at the $10 \%-, 5 \%-$, and $1 \%$-level, respectively. The respective complete first stage regression results for all instrumented variables are available on request from the authors. 